OPEN ACCESS

Edited by:

Anouschka R. Hof,

Wageningen University and Research,

Netherlands

Reviewed by:

Ron Moen,

University of Minnesota Duluth,

United States

Knut Kielland,

University of Alaska Fairbanks,

United States

*Correspondence: Nathan R. De Jager

ndejager@usgs.gov

Specialty section:

This article was submitted to Biogeography and Macroecology,

a section of the journal

Frontiers in Ecology and Evolution

Received: 18 March 2020

Accepted: 14 August 2020

Published: 08 September 2020

Citation:

De Jager NR, Rohweder JJ and Duveneck MJ (2020) Climate Change

Is Likely to Alter Future Wolf -

Moose - Forest Interactions at Isle

Royale National Park, United States.

Front. Ecol. Evol. 8:543915.

doi: 10.3389/fevo.2020.543915

\section{Climate Change Is Likely to Alter Future Wolf - Moose - Forest Interactions at Isle Royale National Park, United States}

\author{
Nathan R. De Jager ${ }^{1 *}$, Jason J. Rohweder ${ }^{1}$ and Matthew J. Duveneck ${ }^{2}$ \\ ${ }^{1}$ U.S. Geological Survey, Upper Midwest Environmental Sciences Center, La Crosse, WI, United States, ${ }^{2}$ Harvard Forest, \\ Harvard University, Petersham, MA, United States
}

We evaluated how climate change and variable rates of moose browsing intensity, as they relate to wolf predation, might affect the forests of Isle Royale National Park, Michigan, United States by conducting a modeling experiment. The experiment consisted of contrasting three different scenarios of wolf management and with a static (current conditions) and changing climate (high emissions). Our results indicate that the interactive effects of wolf predation and climate change are likely to be temporally variable and dependent on biogeographic and forest successional processes. During the first 50 years of 120-year simulations, when the effects of climate change were less impactful, higher simulated rates of predation by wolves reduced moose population densities, resulting in greater forest biomass and higher carrying capacities for moose. However, over the longer term, early successional and highly palatable aspen and birch forests transitioned to late successional spruce and fir forests, regardless of climate or predation intensity. After 50 years, the effects of climate change and predation were driven by effects on balsam fir, a late successional conifer species that is fed on by moose. High-intensity predation of moose allowed balsam fir to persist over the long term but only under the static climate scenario. The climate change scenario caused a reduction in balsam fir and the other boreal species that moose currently feed on, and the few temperate species found on this isolated island were unable to compensate for such reductions, causing strong declines in total forest biomass. The direct effects of moose population management via reintroduction of wolves may become increasingly ineffective as the climate continues to warm because the productivity of boreal plant species may not be sufficient to support a moose population, and the isolation of the island from mainland temperate tree species may reduce the likelihood of compensatory species migrations.

Keywords: balsam fir, climate change, moose, trophic cascade, wolf 


\section{INTRODUCTION}

Today's natural resource management agencies are tasked with anticipating how the effects of their decisions are likely to play out over the long term in the face of climate change. Nearterm solutions to some environmental problems could range from counterproductive to ineffective to critically important as time passes and the climate warms. For example, most large mammalian herbivore populations (e.g., moose, elk, and deer) experience some form of population management given their iconic stature and/or importance for recreational and subsistence hunting (Danell et al., 2006). These animals can also alter the structure and function of ecosystems by preferentially foraging on some plant species and avoiding others (Hobbs, 1996; Pastor and Danell, 2003). Consequently, management agencies often use a variety of techniques to locally reduce herbivore populations (e.g., re-introducing predators or conducting controlled harvests) when their populations grow large enough to affect forest resources in ways that cause conflicts with other land management objectives (Demarais et al., 2012). While such actions can have important effects on the plant communities that these animal populations rely on (Terborgh et al., 1999; Ripple and Beschta, 2012), so too can climate change (Iverson et al., 2008). Will population management actions continue to be effective as the climate warms? Will population management actions become increasingly important? More generally, will the ecosystems that currently support large mammalian herbivore populations continue to do so in the future, with or without population management?

These are some of the questions facing the U.S. National Park Service (NPS) as they begin to manage the moose population of Isle Royale National Park via the reintroduction of wolves. Moose and wolves have co-existed at Isle Royale since at least the 1940s (Murie, 1934; Allen, 1993; Peterson and Page, 1988). For about the past 50 years, the moose population has generally fluctuated between 1 and 2 per square kilometers $\left(\mathrm{km}^{2}\right)$ (500-1200 individuals) while the wolf population has fluctuated between 25 and 50 per $1000 \mathrm{~km}^{2}$ (15-30 individuals) (Peterson et al., 2014). However, inbreeding depression among wolves began to take its toll on the wolf population beginning in the early 2000s (Vucetich et al., 2012), reducing the population to just a lone pair by 2017 . Following several years of increasing moose population density and a multi-year environmental impact assessment (National Park Service [NPS], 2017), the NPS began re-introducing wolves during the winter of 2018-2019. There are currently 17 wolves on the island and the goal of the project is to bring the population up to a total of 20-30 animals. The primary purpose of wolf reintroduction was to reduce the growing moose population and its effects to the forest ecosystem (National Park Service [NPS], 2017). Although the decision to re-introduce wolves to Isle Royale was made with some consideration of the effects of climate change (Fisichelli et al., 2013), there have been no systematic studies of the projected effects of climate change on the vegetation of Isle Royale, or how climate change might interact with moose browsing to alter forest dynamics. This is despite recognition that the island is already being exposed to significant climate changes (Monahan and Fisichelli, 2014). It is therefore unclear what the long-term effects of wolf re-introduction might be as the climate warms and the vegetation of Isle Royale responds to it.

Most of the forested area of Isle Royale is in boreal hardwood ( $\sim 35 \%)$ and boreal conifer ( $\sim 40 \%)$ cover (Figure 1; The Nature Conservancy [TNC], 1999). Moose browsing has been shown to accelerate forest succession from the shade intolerant and rapidly growing hardwood species such as paper birch (Betula papyrifera) and quaking aspen (Populus tremuloides) to the more shade tolerant and slower growing conifer species such as white and black spruce (Picea glauca and P. mariana) because moose preferentially feed on the former and avoid the latter (Snyder and Janke, 1976; McInnes et al., 1992). In most North American boreal forests, balsam fir (Abies balsamea) is also associated with later successional spruce-fir forests (Bergeron, 2000). But at Isle Royale, moose heavily feed on balsam fir during the winter, reducing its abundance in boreal conifer forests (Brandner et al., 1990). In areas that have received very high annual rates of moose browsing, moose-spruce-savannahs have emerged following the loss of nearly all woody plant species, except for unbrowsed spruce (Rotter and Rebertus, 2015). The remaining forest cover of Isle Royale is composed of species more frequently associated with temperate forests. Northern hardwood species such as sugar maple (Acer saccharum) and yellow birch (B. alleghaniensis) are locally abundant on the western end of Isle Royale but make up only $10 \%$ of the total forest area of the island, while northern conifer forests (northern white-cedar (Thuja occidentalis) make up the remaining $15 \%$ or so of total forest area (Figure 1; The Nature Conservancy [TNC], 1999). These communities are dominated by long-lived species, often typical of late-successional old-growth temperate forests, but moose feed on all of them. As a result, heavy browsing may slow the rate of forest succession to these communities depending on browsing intensity (Sell, 2007).

Isle Royale National Park is situated in the North American temperate - boreal forest transition zone (Goldblum and Rigg, 2010) and is therefore thought to be highly susceptible to effects of climate change (Fisichelli et al., 2013). Both the boreal and temperate tree communities found there are growing near their southern and northern range limits, respectively, and are therefore considered to be sensitive to changes in temperature and/or precipitation (Fritts, 1976; Reich and Oleksyn, 2008). The upper Midwest region has shown an upward trend in mean minimum, mean maximum, and mean temperature in all seasons from 1901-2011 (Handler et al., 2013. Future projections for the twenty-first century indicate upward trends in temperature for the Midwest between 2.8 and 4.9 degrees Celsius $\left({ }^{\circ} \mathrm{C}\right)$ by the end of the century, depending on emissions scenario (Intergovernmental Panel on Climate Change [IPCC], 2007; Gonzalez et al., 2010; Kunkel et al., 2013). Further, a recent examination of temperature trends at Isle Royale National Park showed similar trends in both annual mean temperature and mean temperature during the warmest quarter (summer months) as found for mainland areas (Monahan and Fisichelli, 2014). While projected changes in precipitation are more variable, a general decrease in precipitation is projected for high emissions scenarios in the upper Midwestern U.S. summer months after 2050 (Stoner et al., 2012). Current measurements of greenhouse 


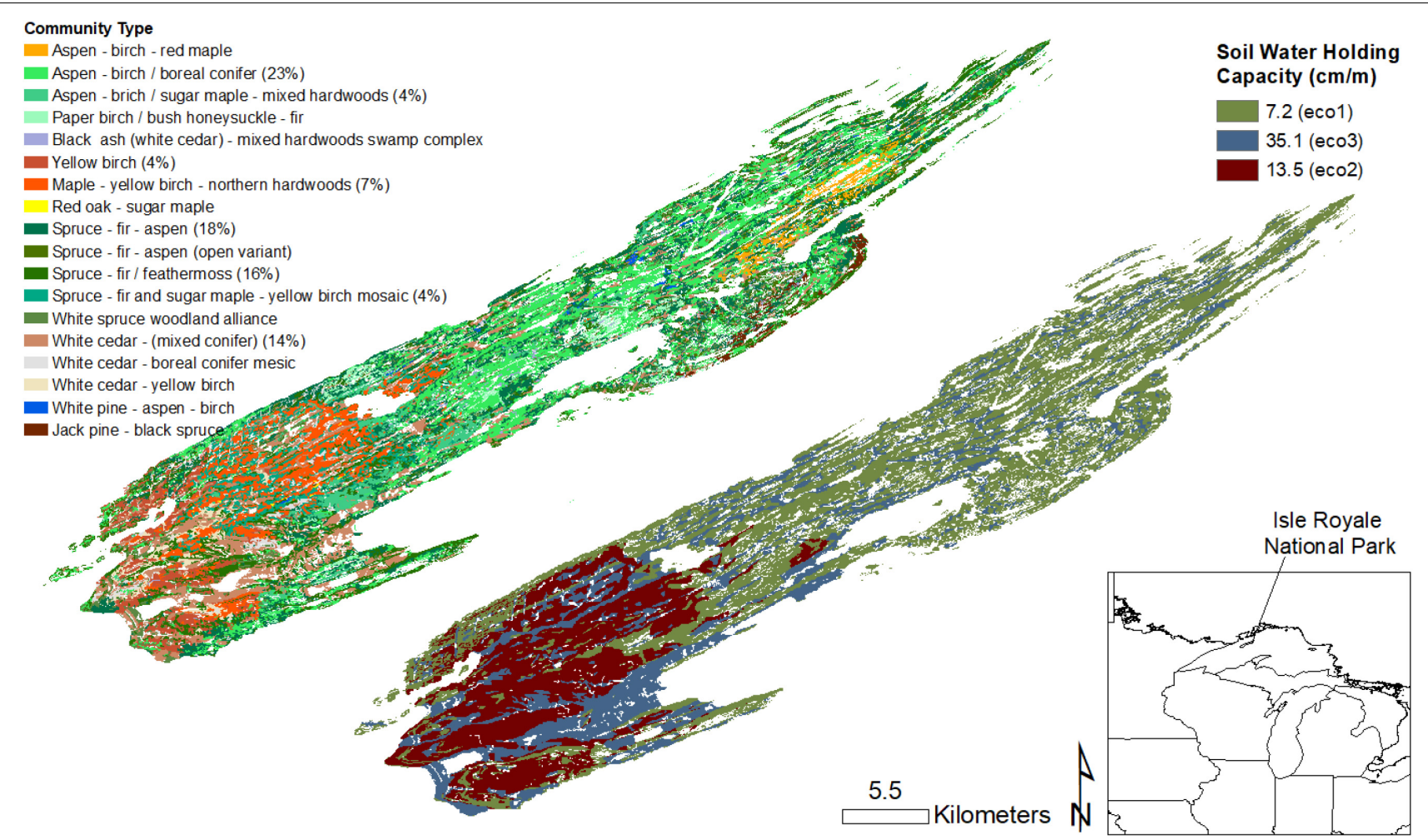

FIGURE 1 | Forest community types and soil water holding capacity representing initial conditions (c. 2006) at Isle Royale National Park. Percentage of total forest cover is provided for forest communities making up greater than $3 \%$ total forest cover. Forest plot data were imputed into the areas of similar forest community types to create the initial age and species distribution maps for modeling. Soil water holding capacity was used to delineate ecoregions, which influence rates of species establishment and growth.

gas emissions have been near the highest projected emissions scenario (A1FI) (Intergovernmental Panel on Climate Change [IPCC], 2007; Peters et al., 2012) and recent modeling studies indicate that the associated projected changes in temperature and precipitation for nearby northeastern Minnesota are sufficient to cause reductions in the establishment and growth rates of boreal tree species (e.g., spruce, fir, aspen, and birch), with less negative effects and some positive effects of climate change on a suite of temperate deciduous species [e.g., sugar maple, yellow birch, red maple (Acer rubrum), and red oak (Quercus rubra)] (Duveneck et al., 2014a). These results indicate that northern hardwood forests could begin to replace the boreal forests across Isle Royale. However, other studies also conducted in nearby northern Minnesota have shown that the negative effects of herbivory on the growth of temperate forest species could offset any positive effects of increasing temperatures, limiting the ability of temperate species to replace boreal species (Fisichelli et al., 2012). Furthermore, temperate species currently have a limited distribution at Isle Royale, and it is possible that the negative effects of climate change on boreal forests will outpace rates of dispersal by temperate species (Sanders and Grochowski, 2013). In either case, rather than simply experiencing a shift in the distribution of forest community types, Isle Royale could experience significant reductions in both forest productivity and biodiversity, and/or develop novel plant communities, with potentially significant implications for the ability of the landscape to support a moose population over the long term.

This study builds from earlier modeling studies to better understand and project the future forests of Isle Royale National Park under different scenarios of wolf management (De Jager et al., 2017b) and with projected effects of climate change on tree species establishment and growth rates (Duveneck et al., 2014a,b; Duveneck and Scheller, 2015a,b). While these previous modeling studies have examined effects of moose browsing and climate change independent of each other, the present study is the first to examine how they may interact with each other. Our objectives were to evaluate how climate change and variable rates of moose browsing intensity, as they relate to wolf predation, may affect the forests of Isle Royale National Park. We specifically addressed the following questions: (1) How does predation by wolves influence moose population dynamics and the effect of moose browsing on patterns of forest succession and productivity with and without climate change? (2) Are northern hardwood forests able to replace boreal forests as the climate warms and does this phenomenon depend on rates of wolf predation? (3) In general, can Isle Royale support both a healthy forest and a moose population over the long-term in the face of climate change, and how much does the answer depend on the rate of predation by wolves? 


\section{MATERIALS AND METHODS}

\section{Study Area}

Isle Royale is an archipelago in the northwestern part of Lake Superior (Figure 1). The main island is $\sim 24$ kilometers $(\mathrm{km})$ from the shore of northeastern Minnesota, USA and southern Ontario, Canada, and is $\sim 534 \mathrm{~km}^{2}$. The island has a distinct ridge and valley topography that reflects the angle of the most recent glacial stage $[\sim 11,000$ years before present (bp)]. De Jager et al. (2017a) recently characterized major differences in soils across the island, important for structuring vegetation communities. These differences were represented by calculating soil water holding capacity (SWHC) in units of centimeters per meter $(\mathrm{cm} / \mathrm{m})$ within 1 meter $(\mathrm{m})$ of soil depth (Web Soil Survey, 2011). The data were then grouped into three zones of relatively homogeneous SWHC: thin soils over bedrock with low SWHC (mean of $7.2 \mathrm{~cm} / \mathrm{m}$ ), deeper soils (mean SWHC of $13.5 \mathrm{~cm} / \mathrm{m}$ ), and alluvial soils with high SWHC (mean of $35.1 \mathrm{~cm} / \mathrm{m}$ ). The climate of Isle Royale is similar to that of northeastern Minnesota, with mean daily high temperatures in summer (June, July, and August) of $\sim 20-$ $21^{\circ} \mathrm{C}$ and mean daily high temperatures in winter (December, January, February) near $-3^{\circ} \mathrm{C}$. A recent assessment of climate change exposure for the U.S. National Parks found upward trends in mean annual temperature and mean temperature during summer for Isle Royale and other midwestern National Parks (Monahan and Fisichelli, 2014). Thus, Isle Royale, like the nearby mainland, is already experiencing significant climate change. Local observations indicate that there may be a gradient in temperature from the interior of the island to the shore of Lake Superior during summer. However, gridded climate data (PRISM, Daly and Gibson, 2002) described very little spatial variability in temperature or precipitation across the island. We therefore considered the entire island to be a single climate zone and developed an ecoregional geographic information system (GIS) coverage (50-m cell size) based on SWHC alone (Figure 1). This ecoregional coverage influences the potential establishment and growth rates of different tree species as described below (see "Landscape Simulation Modeling").

The vegetation of Isle Royale is characteristic of the temperateboreal forest transition zone (Goldblum and Rigg, 2010; Sanders and Grochowski, 2013). For this study, we used a map of the vegetation communities developed in the late 1990s (The Nature Conservancy [TNC], 1999), which included 18 different plant community assemblages (Figure 1). The most abundant communities across the main island were Aspen-birch/boreal conifer forests (21\%), spruce-fir-aspen forest (16\%), sprucefir/feathermoss forest $15 \%$, white cedar- (mixed conifer)/alder swamp (13\%), maple - yellow birch -northern hardwoods forest $(7 \%)$. Although some communities were relatively rare (e.g., red oak - sugar maple forest, < 1\%) we included them given their potential to expand under climate change. The species composition of forest inventory plots was then used to match each mapped forest community type with multiple forest inventory plots collected for the U.S. Forest Service Forest Inventory and Analysis (FIA) (Woudenberg et al., 2010) and the inventory plots were randomly imputed within each matched forest community type to develop a GIS coverage (50-m cell size) as described in previous modeling studies (e.g., De Jager et al., 2017a). Ages of each tree in the inventory dataset were then estimated using site index curves following the methods outlined in De Jager et al. $(2017 \mathrm{a}, \mathrm{b})$. Finally, each tree was grouped into cohorts at 25-year age intervals, with all seedlings and any age 10 or younger tree assigned an age of 5 years. Although the current study used a similar methodology to develop this initial plant community dataset as that described in De Jager et al. (2017a,b), the present study included several additional rare temperate species and community types. Thus, results of this study may not be directly comparable to the previously published studies.

\section{Landscape Simulation Modeling}

We used the LANDIS-II forest simulation modeling platform (Scheller et al., 2007). LANDIS-II simulates successional processes, disturbances, seed dispersal, growth and mortality across a series of grid cells (i.e., the landscape). Such processes are represented with different extensions that allow users to determine the degree of complexity needed to represent different systems. We used the Biomass Succession Extension (version 3.2; Scheller and Mladenoff, 2004) to simulate establishment, growth, and competition across the landscape as these properties affect and are affected by the biomass of species-age-cohorts. Biomass Succession requires input parameters for potential species establishment probabilities $\left(P_{\text {est }}\right)$, which represent the likelihood of establishment of a new cohort given a seed source and adequate light, and maximum growth rate $\left(\mathrm{ANPP}_{\max }\right)$ and maximum aboveground biomass $\left(\mathrm{AGB}_{\max }\right)$, which determine the potential aboveground growth of a cohort. These parameters can vary spatially and temporally as they relate to annual temperature and precipitation patterns and the underlying soil characteristics. We used previously published establishment and growth parameters for the species listed in Table $\mathbf{1}$ developed by Duveneck et al. (2014a) in northeastern Minnesota for ecoregions of similar climate and soil conditions as that found at Isle Royale, and for two climate scenarios (current climate and high emissions, see below). Thus, the effect of climate change in this study was represented as a temporal change in the potential establishment and growth rates of the species growing on different soils at Isle Royale and in response to variable temperature and precipitation patterns. Duveneck et al. (2014a) used the PnET-II ecophysiology model (Xu et al., 2009) to estimate $P_{\text {est }}, \mathrm{ANPP}_{\max }$, and $\mathrm{AGB}_{\max }$ using input climate data for current climate conditions and that of the high emissions scenario (A1FI) for northeastern Minnesota and based on several species-specific physiological characteristics. These input parameters are provided in Figure A1, and provide some insights into potential species-specific effects of climate change. However, within the Biomass Succession extension, the actual growth of a cohort incorporates a species-specific growth parameter to determine how fast the actual growth rate (ANPP) reaches $\mathrm{ANPP}_{\max }$. Further, growth is also modified by competition and age. Competition is represented by the available growing space, and age-related mortality is represented by an increasing decline in growth as cohorts near longevity. Finally, actual species establishment rates are strongly affected by seed supply and 
TABLE 1 | Tree species life history parameters used in forest simulation modeling for the species modeled at Isle Royale National Park.

\begin{tabular}{|c|c|c|c|c|c|c|c|c|c|c|}
\hline \multirow[t]{2}{*}{ Species } & \multirow{2}{*}{$\begin{array}{c}\text { Longevity } \\
\text { (year) }\end{array}$} & \multirow{2}{*}{$\begin{array}{c}\text { Maturity } \\
\text { (year) }\end{array}$} & \multicolumn{2}{|c|}{ Tolerance } & \multicolumn{2}{|c|}{ Seed Dispersal (m) } & \multirow{2}{*}{$\begin{array}{l}\text { Vegetative } \\
\text { reproduction } \\
\text { (Prob) }\end{array}$} & \multicolumn{2}{|c|}{ Sprout age } & \multirow{2}{*}{$\begin{array}{c}\text { Postfire } \\
\text { regeneration }\end{array}$} \\
\hline & & & Shade & Fire & Effective & Maximum & & Minimum & Maximum & \\
\hline A. balsamea & 205 & 20 & 50 & 1 & 30 & 160 & 0 & 0 & 0 & None \\
\hline A. rubrum & 150 & 10 & 4 & 1 & 100 & 200 & 0.1 & 0 & 60 & Resprout \\
\hline A. saccharum & 300 & 40 & 5 & 1 & 100 & 200 & 0.1 & 0 & 60 & None \\
\hline B. alleghaniensis & 300 & 40 & 4 & 2 & 100 & 400 & 0.1 & 0 & 180 & None \\
\hline B. papyrifera & 165 & 25 & 2 & 2 & 200 & 5000 & 0.5 & 0 & 70 & Resprout \\
\hline F. nigra & 150 & 35 & 2 & 1 & 100 & 200 & 0.1 & 0 & 75 & Resprout \\
\hline P. banksiana & 205 & 17 & 1 & 4 & 20 & 275 & 0 & 0 & 0 & None \\
\hline P. glauca & 225 & 40 & 3 & 2 & 30 & 200 & 0 & 0 & 0 & None \\
\hline P. mariana & 200 & 22 & 3 & 3 & 80 & 200 & 0.1 & 0 & 100 & Resprout \\
\hline P. strobus & 450 & 15 & 3 & 3 & 60 & 210 & 0.5 & 25 & 300 & None \\
\hline P. tremuloides & 140 & 25 & 1 & 1 & 1000 & 5000 & 0.9 & 0 & 100 & Resprout \\
\hline Q. rubra & 250 & 25 & 2 & 4 & 30 & 3000 & 0.5 & 25 & 180 & Resprtout \\
\hline Shrub & 100 & 25 & 3 & 1 & 45 & 60 & 0.5 & 0 & 60 & Resprout \\
\hline T. occidentalis & 300 & 35 & 5 & 1 & 45 & 60 & 0.5 & 50 & 300 & None \\
\hline
\end{tabular}

light conditions. Thus, model outcomes depend on both the potential establishment and growth rates (Figure A1) and how local and landscape scale factors modify them over the course of model simulations.

We simulated the effects of predation on moose population density and dynamics and resulting feedbacks with browsing patterns and forest succession using the Dynamic Ungulate Browse Extension (Version 0.8). Readers are directed to De Jager et al. (2017a,b) for complete details of the browse extension as it is only briefly and generally discussed here. The browse extension simulates reciprocal interactions, at an annual time step, between an ungulate population and forest succession through annual estimates of available forage biomass. Available forage biomass is a fraction of the total speciescohort biomass considered to be available to a foraging ungulate across an entire year. These calculations take into account how long tree species remain within the height reach of a foraging animal and the fraction of total aboveground biomass in edible leaves (summer) and twigs (winter). In previous applications of the browse extension, total annual available forage biomass was generally near $0.1-0.2 \%$ of total forest biomass (De Jager et al., 2017b). The ungulate population is temporally dynamic and governed by a discrete-time quadratic model, with a carrying capacity term that is derived at each time step (year) based on how many animals could be supported by the total available forage biomass for all species-cohorts across the landscape. Thus, the carrying capacity of the landscape is an emergent property, rather than a pre-defined parameter estimate. This means that the animal populations density is also an emergent property, rather than being predefined. Other factors that can influence the annual moose population density include: (1) the intrinsic population growth rate, which was randomly selected each annual time step between 0.15 and 0.25 , (2) random population mortality rate (0 to 0.1$),(3)$ animal harvest rate $(0)$, and (4) predation rate (see scenarios below). These parameter settings reflect empirical estimates derived from a long-term moose-wolf study conducted at Isle Royale National Park (Peterson et al., 2014 and references within). The initial population density was set to 1 moose per $\mathrm{km}^{2}$, reflecting the long-term mean population density.

Within each year, the local ungulate population density (and hence how much forage biomass is removed from a site) is determined by downscaling and distributing the total population to each grid cell. This process is done using moving window calculations of site preference (forage quality and quantity) at each time step. Thus, the ungulate population can fluctuate from year to year and place to place based on how any factor influences the availability and quality of forage biomass over time and space, including the ungulate population itself. We derived estimates of forge preference (quality) based on previously published studies conducted at Isle Royle (Table 2). For estimates of annual forage preference, we relied heavily on Hodgson (2010) because that study utilized data collected annually (summer and winter foraging preferences). These parameter estimates represent the fraction of available forage biomass that the ungulate population would be expected to remove from each species present at a site, based on the literature identified in Table 2 .

At each time step, the total available forage biomass removed from each grid cell (a site) is the amount needed to satisfy the requirements of the local ungulate population. How much biomass is removed from each species at a site depends on the preference of the population for each species (given in Table 2) at each site. Effects of removed biomass on the growth and survival of tree cohorts were simulated using threshold equations, whereby a user-specified proportion of biomass lost due to browsing triggers a negative growth response in the next time step, up to user-defined maximum negative effect at $100 \%$ removal of available forage biomass. We used the same parameter estimates for species preferences and effects of moose browsing on growth and survival as published in De Jager et al. (2017b) (see Table 2). 
TABLE 2 | Species-specific model parameters for moose browsing preference and effects of browsing on growth and mortality.

\begin{tabular}{|c|c|c|c|c|c|}
\hline \multirow[t]{2}{*}{ Species } & \multirow[t]{2}{*}{ Preference } & \multicolumn{2}{|c|}{ Growth reduction } & \multicolumn{2}{|c|}{ Mortality } \\
\hline & & Threshold & Max & Threshold & Max \\
\hline A. balsamea ${ }^{1,2,4,6}$ & 0.15 & 0.2 & 0.6 & 0.8 & 0.1 \\
\hline A. rubrum & 0.30 & 0.2 & 0.6 & 0.8 & 0.1 \\
\hline A. saccharum 2,3,6 & 0.15 & 0.2 & 0.6 & 0.8 & 0.1 \\
\hline B. alleghaniensis $2,3,6$ & 0.15 & 0.2 & 0.6 & 0.8 & 0.1 \\
\hline B. papyrifera $2,5,6$ & 0.25 & 0.5 & 0.4 & 0.9 & 0.1 \\
\hline F. nigra ${ }^{1,2,6}$ & 0 & 0 & 1 & 0.8 & 0.1 \\
\hline P. banksiana ${ }^{1,2,6}$ & 0 & 0 & 1 & 0.8 & 0.1 \\
\hline P. glauca ${ }^{1,2,6}$ & 0 & 0 & 1 & 0.8 & 0.1 \\
\hline P. mariana $a^{1,2,6}$ & 0 & 0 & 1 & 0.8 & 0.1 \\
\hline P. strobus & 0.05 & 0.2 & 0.6 & 0.8 & 0.1 \\
\hline P. tremuloides ${ }^{1,2,3,6}$ & 0.30 & 0.5 & 0.4 & 0.9 & 0.1 \\
\hline Q. rubra & 0.05 & 0.2 & 0.6 & 0.8 & 0.1 \\
\hline shrub1,2,6 & 0.25 & 0.5 & 0.4 & 0.9 & 0.1 \\
\hline T. occidentalis ${ }^{1,2,6,7}$ & 0.05 & 0.2 & 0.6 & 0.8 & 0.1 \\
\hline
\end{tabular}

The threshold parameters represent the proportion of available forage biomass, that once removed trigger growth reduction or an increase in the probability of mortality. Growth reduction or mortality increase linearly to a maximum (Max) at 100\% browse removal. ${ }^{1}$ Hodgson (2010). ${ }^{2}$ Risenhoover (1987). ${ }^{3}$ Sell (2007). ${ }^{4}$ De Jager et al. (2009). ${ }^{5}$ De Jager and Pastor (2008). ${ }^{6}$ Murie (1934). ${ }^{7}$ Parikh (2015).

\section{Climate and Predation Scenarios}

We contrasted two climate scenarios: static or current climate, and a high emissions scenario as described in Duveneck et al. (2014a). Static climate was simulated by randomly selecting simulation years from 30 (1969-1999) past observed climate years (Daly and Gibson, 2002). We represented climate change using the A1FI high emissions scenario of the Intergovernmental Panel on Climate Change [IPCC] (2007) coupled to the Geophysical Fluid Dynamics Laboratory (GFDL) Global Circulation Model (GCM) given its sensitivity to emissions (Delworth et al., 2006). Our climate change scenario reflected an accurate representation of observed global emissions at the time it was developed (Raupach et al., 2007). Since then, additional climate change scenarios have been developed by the IPCC. Importantly, the high emissions scenario used here (A1FI) is similar to the more recent Coupled Model Intercomparison Projects (CMIP) scenarios CMIP5 (RCP8.5) and CMIP6 (SSP5-8.5), with similar end of century radiative forcing and global mean temperature projection (O'Neill et al., 2016). Briefly, the high emissions scenario indicates increased temperature in the Midwest in all seasons for the next 100 years with most of the increase in temperature after 2050. Likewise, the high emission scenario indicates variable but decreasing precipitation in summer months after 2050 (Stoner et al., 2012). We simulated climate (temperature and precipitation patterns) across the entire island using results from Duveneck et al. (2014a) for the coldest and northern-most climate region (climate region 1) in nearby NE Minnesota from 2006-2116. Thus, we compared a high emissions (climate change) scenario with a static (current climate) scenario. For a graphical representation of how projected temperature and precipitation patterns differ between our static and high emissions scenarios, see Duveneck et al. (2014a). It is important to note that within our modeling framework, climate change does not directly impact moose population density. Thus, impacts of climate change on carrying capacity or the moose population come about via indirect effects on plant growth.

We evaluated the effects of predation by varying the predation rates within the ungulate browsing extension. We contrasted a no predation scenario $(P=0)$ with a weak predation scenario $(P=0.03-0.10)$, reflecting long-term mean predation rates (Peterson et al., 2014), and finally a strong predation scenario $(P=0.07-0.15)$, reflecting above-mean long-term predation rates (Peterson et al., 2014). At each annual time step, a random predation rate between the above intervals was selected to represent stochastic variation in predation rates within a scenario replicate. Unlike the effects of climate change, simulated effects of predation directly reduce moose population density. Such effects can further feedback to alter plant growth and carrying capacity by reducing browsing effects. We simulated a total of 6 scenarios (3 predation X 2 climate scenarios) for 120 years (2006-2126, $\sim 100$ years from today). For each scenario, we ran three replicates given the stochastic nature of the model.

\section{Data Analysis}

We evaluated moose population dynamics by estimating the island-wide population density, carrying capacity, and a habitat suitability index for each annual time-step. Population density and carrying capacity were calculated as the number of animals per island area $\left(\# / \mathrm{km}^{2}\right)$. We calculated habitat suitability as the normalized sum of area-weighted total forage biomass (quantity) and site preference (quality) on a $0-100$ scale. We evaluated forest successional patterns by calculating the total aboveground live biomass of different groups of indicator species. Black and white spruce were grouped into a single category (spruce); northern conifers included northern white cedar, white and jack pine; boreal hardwoods included aspen and paper birch; northern hardwoods included yellow birch, sugar maple, red maple, red oak, and black ash. For all outputs we calculated the mean and 2 standard deviations to evaluate statistical overlap among scenarios over time. These standard deviations were included in all figures, but in some cases were very small and not noticeable. For scenarios with standard deviations that appeared to be larger than others (e.g., strong predation under current climate), we ran additional replicate simulations to verify results were not driven by a single outlier replicate. We constructed maps for initial conditions (year 2006) and ending conditions (year 2126) for the scenarios that consisted of: (1) no climate change and no predation, (2) no climate change and strong predation, (3) climate change and no predation, and (4) climate change and strong predation. These maps can be found in Figure A2.

\section{RESULTS}

\section{Moose Population Dynamics}

Moose population densities were greatest at 3-4 moose per $\mathrm{km}^{2}$ for the "no predation" scenarios. Indeed, moose population densities were largest for scenarios that did not include predation 


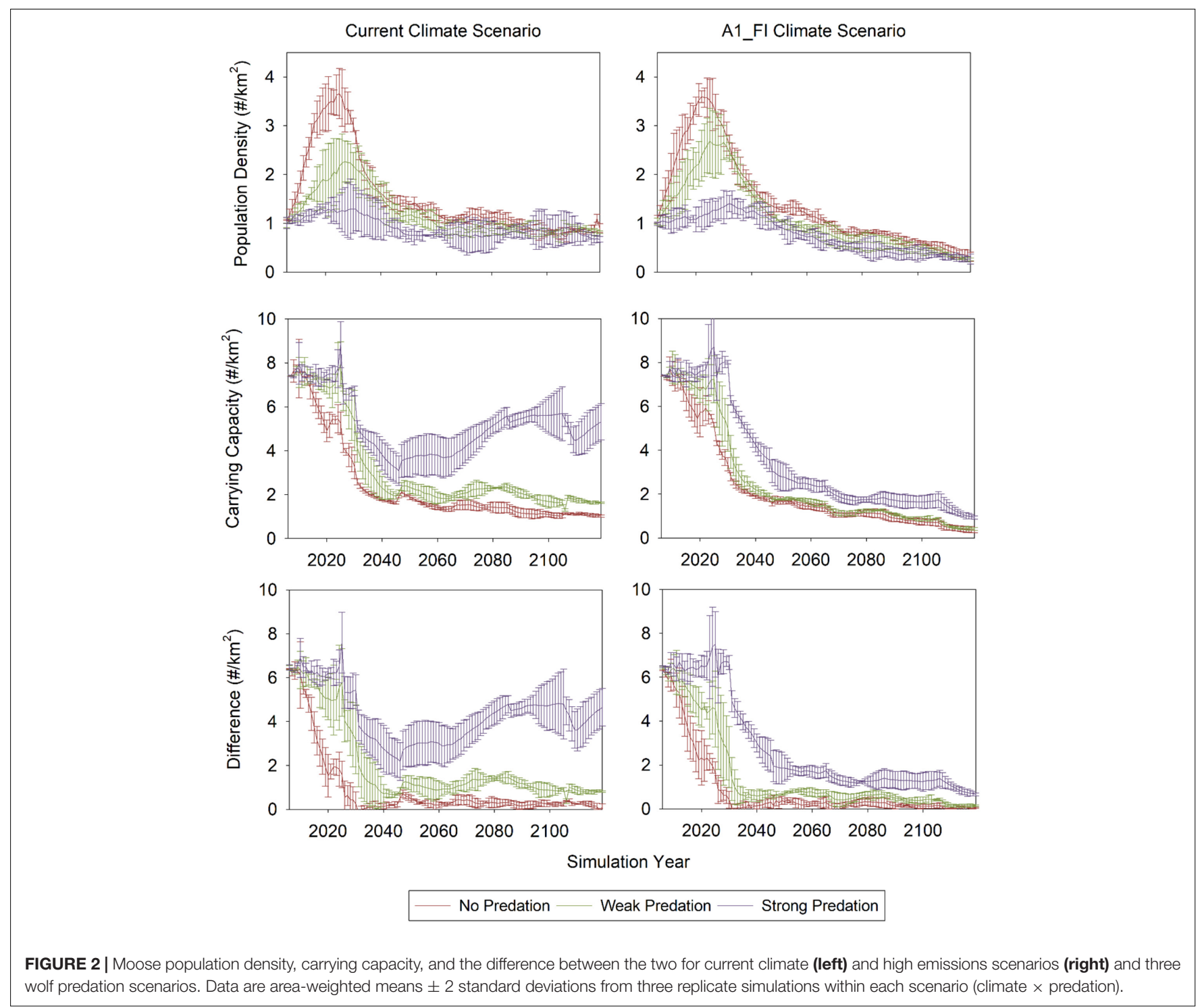

by wolves during the first 30 years of model simulations, regardless of the climate change scenario (Figure 2). Weak predation yielded peak moose population densities between 1.5 and 2.5 per $\mathrm{km}^{2}$, while strong predation kept moose population densities below 2 per $\mathrm{km}^{2}$ for the duration of model simulations.

In contrast to the near-term direct effects of predation on moose population density, climate change had almost no effect on population density in the near term, but had a minor effect on population density over the long term as it began to influence plant growth and establishment (forage production and carrying capacity) after 30 to 50 years. Late in the simulations (i.e., after 2060), moose population densities decreased for all three predation scenarios under the climate change scenario, in contrast to more stable moose population densities under the current climate scenario (Figure 2). These declines were due to reduced growth and establishment of boreal tree species in the diet of moose (Figure A1) and an apparent lack of compensatory growth by temperate species.
Differences in peak population density among scenarios had important consequences for longer-term estimates of carrying capacity, given the long-term effects of moose browsing on plant growth and available forage biomass. The lower peak population densities in the strong predation scenarios kept more forage biomass on the landscape and allowed for larger estimates of carrying capacity, especially under static climate conditions, but there were also more marginal effects under climate change (Figure 2). In these scenarios, predation continued to limit moose population density despite relatively higher carrying capacities, which in turn contributed to larger differences between carrying capacity and population density under both static and changing climate (Figure 2). The difference between carrying capacity and population density for the strong predation scenario was larger under current climate conditions than under the climate change scenario (Figure 2), reflecting a landscape much more suitable for moose (Figure 3). In contrast to the results for the strong predation scenarios, the higher initial peak population densities 

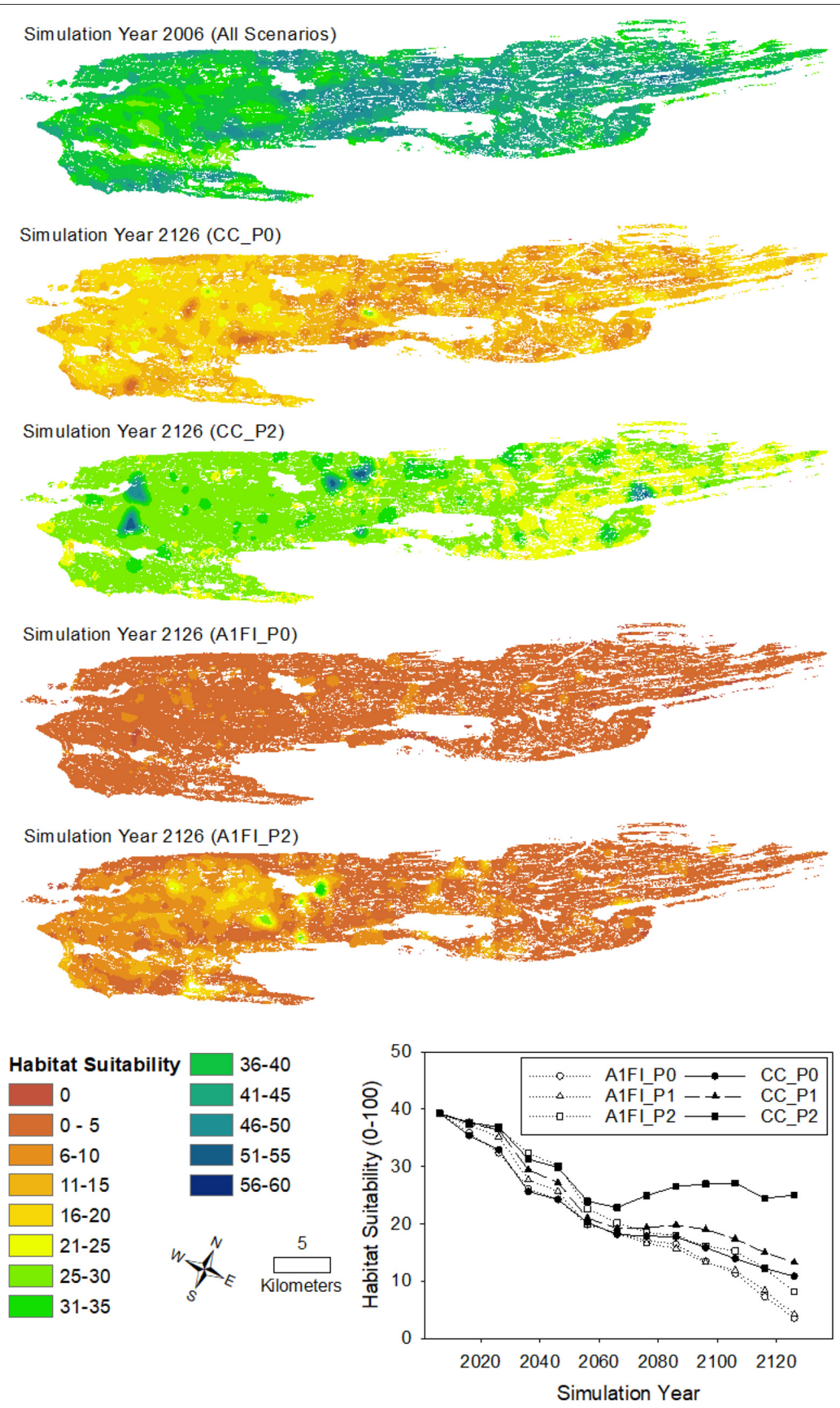

FIGURE 3 | Mapped distributions of habitat suitability for moose based on forage quantity and quality for initial model conditions (simulation year 2006) and after 120 years of current climate and no predation (CC_PO), current climate and strong predation (CC_P2), high emissions and no predation (A1FI_P0), and high emissions and strong predation (A1FI_P2). Inset graph shows the mean habitat suitability for each 10 years for all scenarios (CC_P1 is current climate with weak predation, A1FI_P1 is high emissions with weak predation). 
in the weak and no predation scenarios contributed to lower long-term carrying capacities. This in turn limited long-term population density and kept the moose population much closer to the carrying capacity of the landscape. Thus, in the long-term, predation interacted with climate change to alter available forage biomass and the carrying capacity of the landscape. The largest estimates of carrying capacity and the largest difference between carrying capacity and population density was found for the strong predation scenario under current climate.

Interactive effects of simulated predation and climate also affected moose habitat suitability, which incorporated both the total available forage across the landscape and the quality of that forage (Figure 3). All three predation scenarios coupled to climate change resulted in lower habitat suitability than the current climate scenarios by simulation year 2126. The only scenario that produced significantly higher (non-overlapping CI's) and temporally stable estimates of habitat suitability was the strong predation scenario under current climate conditions. Thus, in our simulations, predation only contributed to a more suitable and sustainable landscape for moose under current climate conditions.

Finally, biomass removed from different species groups differed among predation scenarios early in simulations, during the period of time that predation was influencing population density (Figure 4). Later in simulations, when moose population density was similar across predation scenarios there were no differences in biomass removed among predation scenarios. However, late in the simulations (i.e., after year 2060) the amount of balsam fir removed from the landscape differed among climate change scenarios. Under current climate, the amount of balsam fir removed from the landscape tended to be greater than that removed in the climate change scenarios.

\section{Forest Succession}

The effects of climate change, predation, and forest successional processes also altered species biomass within different forest communities (Figure 5). Across the entire island, aspen and birch forests (boreal hardwoods) and spruce (white and black) forests had the highest initial mean estimates of forest biomass $\left[\sim 4000\right.$ grams per square meter $\left.\left(\mathrm{g} / \mathrm{m}^{2}\right)\right]$ representing current conditions. Under all scenarios, these two species groups diverged immediately, with aspen and birch declining and spruce forests increasing in biomass. The simulated decline in more palatable aspen and birch biomass and increase in unpalatable spruce biomass contributed to the initial declines in both carrying capacity and habitat suitability that also occurred for all scenarios (Figure 2), indicating that forest successional changes had a large effect on moose population dynamics, regardless of the effects of climate change or predation. Though the decline in aspen and birch biomass occurred similarly for all scenarios, the increase in spruce biomass was only similar across scenarios until the year 2070, at which point it began to decrease in response to climate change. The change in spruce biomass drove overall declines in total forest biomass in response to climate change (Figure 5).

The other groups of species made up a much smaller proportion of total forest biomass, but tended to be much more sensitive to the interactive effects of predation and climate change and less dependent on forest successional processes. For example, strong predation aided the biomass of northern hardwood species under both climate scenarios, with the highest estimates of biomass found for current climate conditions, followed by the scenario that included strong predation and effects of climate change. For balsam fir, climate change caused a decline in aboveground biomass, regardless of predation. However, predation maintained a much higher above ground biomass of balsam fir under current climate conditions (Figures 5, 6). The temporal trends in balsam fir biomass were similar to those observed for habitat suitability, indicating that the effects of climate change and predation on this species played a role in both forest succession and moose population dynamics. Yet, balsam fir and northern hardwood species made up just 5\% or less of total forest biomass and thus these changes had no effect on this response variable.

\section{DISCUSSION}

\section{Effects of Predation in a Warming Climate}

Isle Royale National Park has long provided insights into the nature of predator-prey relationships in a forest ecosystem (Peterson et al., 2014). Past research has indicated that wolf predation can play a significant role in reducing and/or redistributing the intensity of moose browsing across the island (Vucetich et al., 2011; Peterson et al., 2014) and that reductions to moose browsing intensity would be expected to change rates of forest succession (Pastor and Naimen, 1992; Pastor et al., 1993; Pastor and Danell, 2003). However, in the absence of a coupled moose browsing-forest successional model, it is not possible to fully evaluate the potential long-term feedbacks between browsing and forest successional changes. In combination with previous modeling results (De Jager et al., 2017a,b), our simulations reveal the importance of the plant life history characteristics that influence rates and trajectories of forest succession, the foraging preferences of moose, and physiological responses to anticipated climate changes. In general, our results demonstrate that predation by wolves can alter how moose interact with forage resources and thereby alter rates and trajectories of forest succession. Such changes can have significant effects on the carrying capacity of the landscape for moose and thus on future moose population density in a dynamical system. However, our simulations also show that such interactions are likely to play out very differently as the forests of Isle Royale continue to shift toward late successional conifer species and especially as the climate continues to warm.

The primary effects of wolf predation were to lower peak moose population densities and maintain a higher abundance of high-quality forage. These effects were primarily found over the first 30-50 years of model simulations, before major changes in succession and before the effects of climate change had yet to significantly affect forest growth and development (see Figure A1). In these earlier simulation years, high rates of predation maintained a landscape with relatively high suitability for moose, even as forest successional changes were shifting 


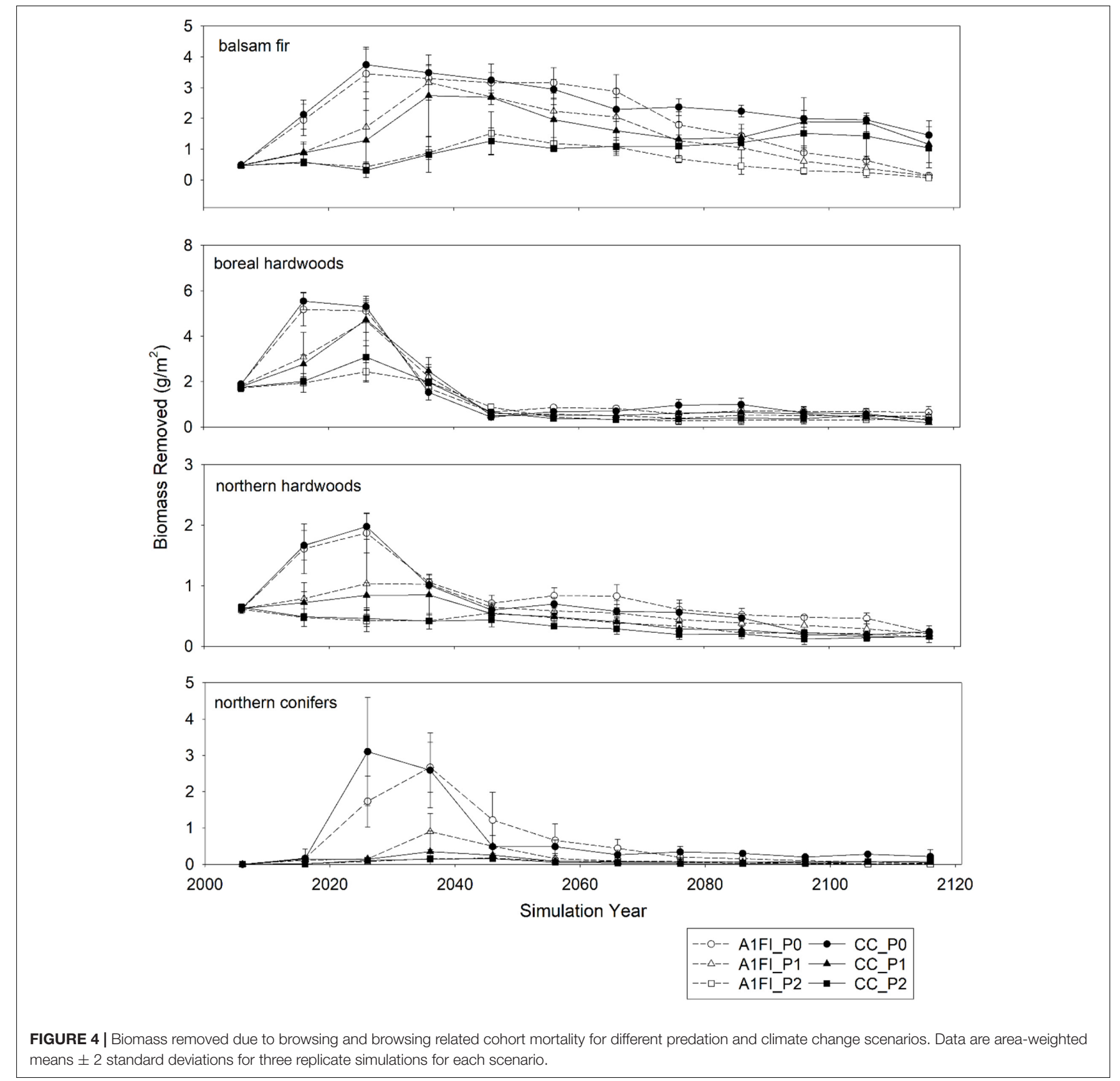

the landscape away from the shade intolerant and fast growing early successional species that moose highly prefer (e.g., aspen and birch) and toward the shade tolerant and slower growing species that they do not eat (spruce). These effects have also been shown in previous modeling studies (De Jager et al., 2017a,b) and exclosure studies (McInnes et al., 1992). However, our model draws attention to the only late successional conifer species that moose feed on, balsam fir. This species benefited most from wolf predation under current climate conditions and appeared to support the moose population over the long-term. Without predation, the successional changes and heavy browsing by moose decreased the carrying capacity of the landscape because browsing and successional changes negatively affected the growth of highly palatable early successional species (e.g., birch and aspen). Climate change further reduced the carrying capacity and suitability of the landscape for moose after 50 years by negatively influencing the growth of balsam fir. These effects were due to increased temperatures later in model simulations as shown in Duveneck et al. (2014a).

\section{Effects of Climate Change and Herbivory in an Island Setting}

Just as Isle Royale has served as a model predator-prey system, it also has characteristics (e.g., it is relatively small, isolated, and 

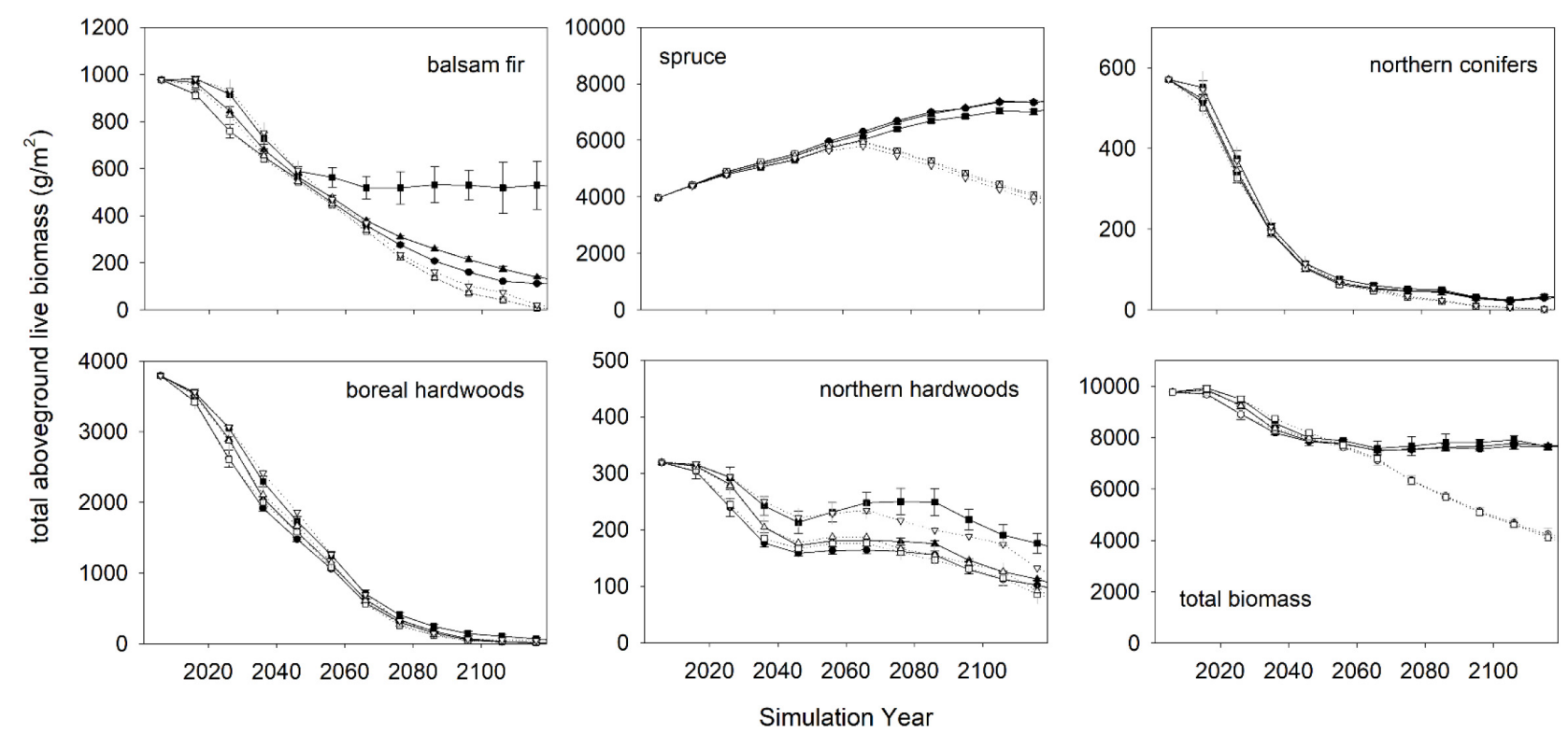

\begin{tabular}{rr|}
\hline$\rightarrow$ CC_P0 & A1FI_P0 \\
$\longrightarrow$ CC_P1 & A1FI_P1 \\
$\rightarrow$ CC_P2 & A1FI_P2 \\
\hline
\end{tabular}

FIGURE 5 | Mean ( \pm 2 standard deviations) total aboveground live biomass of three replicate simulations at 10-year intervals for 120 years of current climate and no predation (CC_P0), current climate and weak predation (CC_P1), high emissions and no predation (A1FI_P0), high emissions and weak predation (A1FI_P1) current climate and strong predation (CC_P2), and high emissions and strong predation (A1FI_P2). See methods for species included in each grouping. In some cases some scenarios overlap each other and are therefore not visible (e.g., total biomass outputs).

has a simplified flora) that can provide insights into the effects of island biogeographic processes on adaptations to climate change. Larger and more well-connected landscapes generally support higher levels of biodiversity, which would be expected to improve the odds of successful species migrations under changing environmental conditions (Cabral et al., 2014). Isle Royale is farther from the mainland than the estimated dispersal distances of several tree species that have been suggested to perform well in a warmer climate (Frelich and Reich, 2009; Sanders and Grochowski, 2013). Thus, without some form of assisted migration of additional temperate species or to expand the distribution of those already present, the vegetation of Isle Royale could begin to shift toward novel plant communities, with implications that extend to the moose population. In our simulations the biomass of temperate forest species, which may be favored with climate change, was not able to fully compensate for the declines in boreal communities as the climate warmed, and predation only marginally influenced this outcome. It is important to note that some of these species (e.g., yellow birch and sugar maple) are relatively shade tolerant and have long lifespans, increasing their importance as forage for moose in late successional forests. Previous studies have indicated that heavy moose browsing may reduce rates of expansion of such northern hardwood forests at Isle Royale National Park (Sell, 2007; De Jager et al., 2017b). Even when aided by potentially positive effects of climate change, browsing by white-tailed deer has been shown to limit the ability of temperate species to replace boreal species (Fisichelli et al., 2012). While our results support the idea that predation by wolves could reduce effects of moose browsing on northern hardwood forests, such effects were insufficient to allow for the expansion of these communities from their initial distributions in the high emissions scenario (Figure A2). Moose may also feed on some of the temperate conifer species that we simulated, such as white and jack pine. However, all temperate species currently have a very limited spatial distribution at Isle Royale, and the rate of climate change may have simply outpaced their ability to disperse as found in other systems (Vanderwel and Purves, 2013; Liang et al., 2017). Furthermore, the simulated effects of climate change on the potential establishment and growth rates of the two most abundant temperate species at Isle Royale (yellow birch and sugar maple) were not uniformly positive (Figure A1). Both species showed initial increases in potential establishment, followed by later declines, and either neutral or negative effects of climate change on potential growth rates. While these effects were less negative than found for boreal species, they did not allow them to compensate for the declines in the biomass of boreal species.

\section{Management Implications}

Our results are not meant to provide precise predictions of the future. Large inherent uncertainty encompasses the processes that we simulated. We cannot predict precise future 


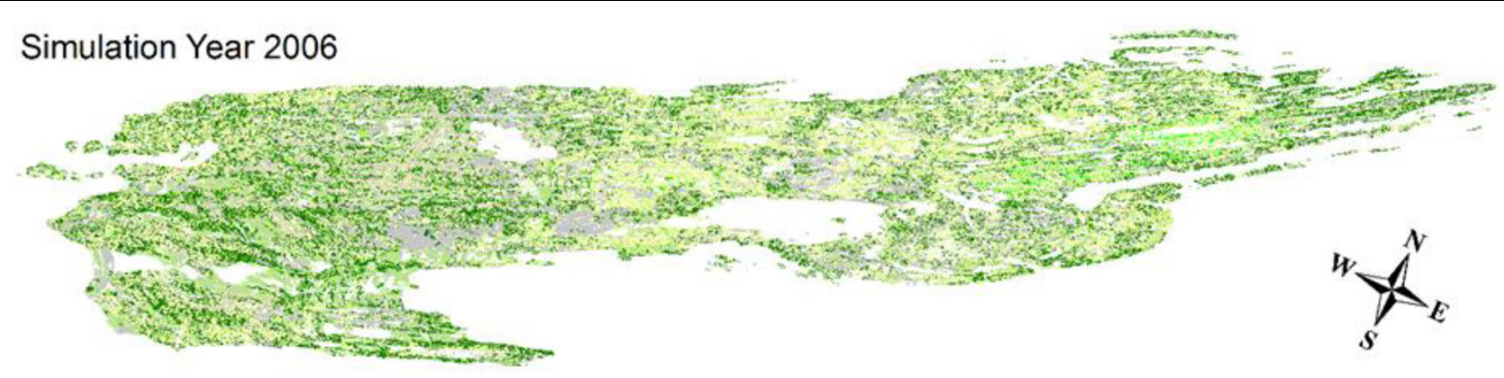

\section{Simulation Year 2126 (CC_P0)}

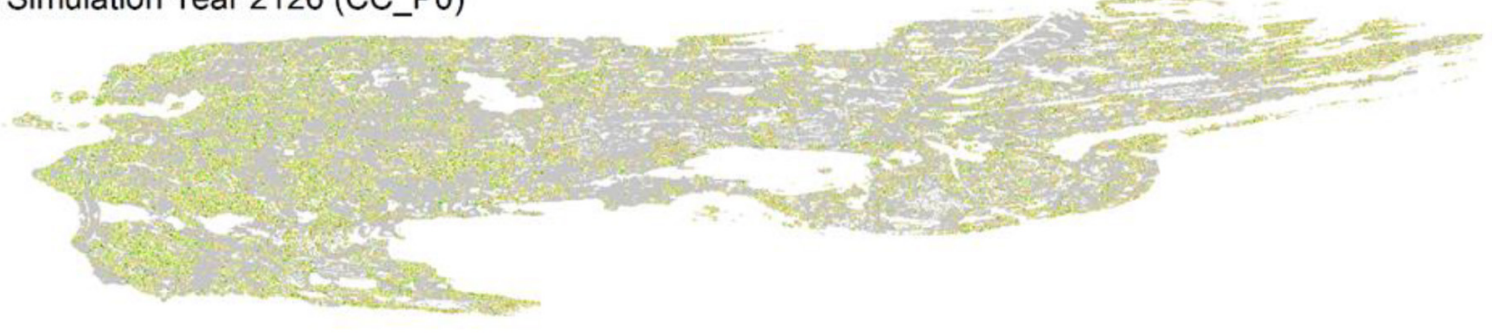

\section{Simulation Year 2126 (CC_P2)}

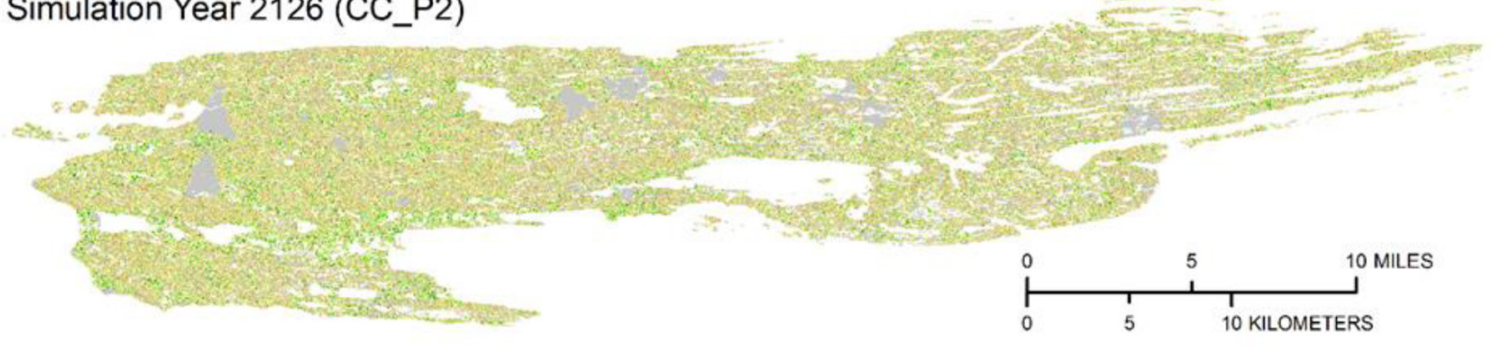

Simulation Year 2126 (A1_P0)

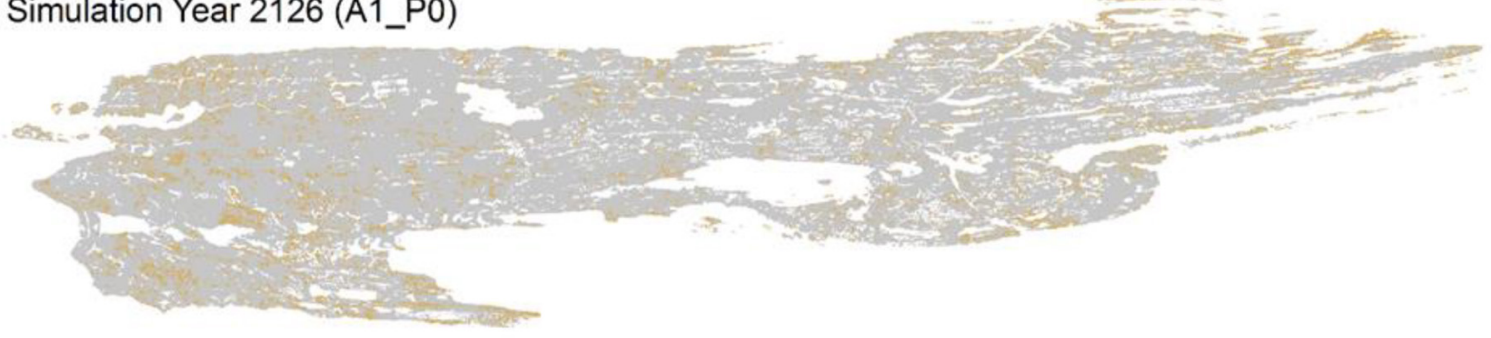

Simulation Year 2126 (A1_P2)

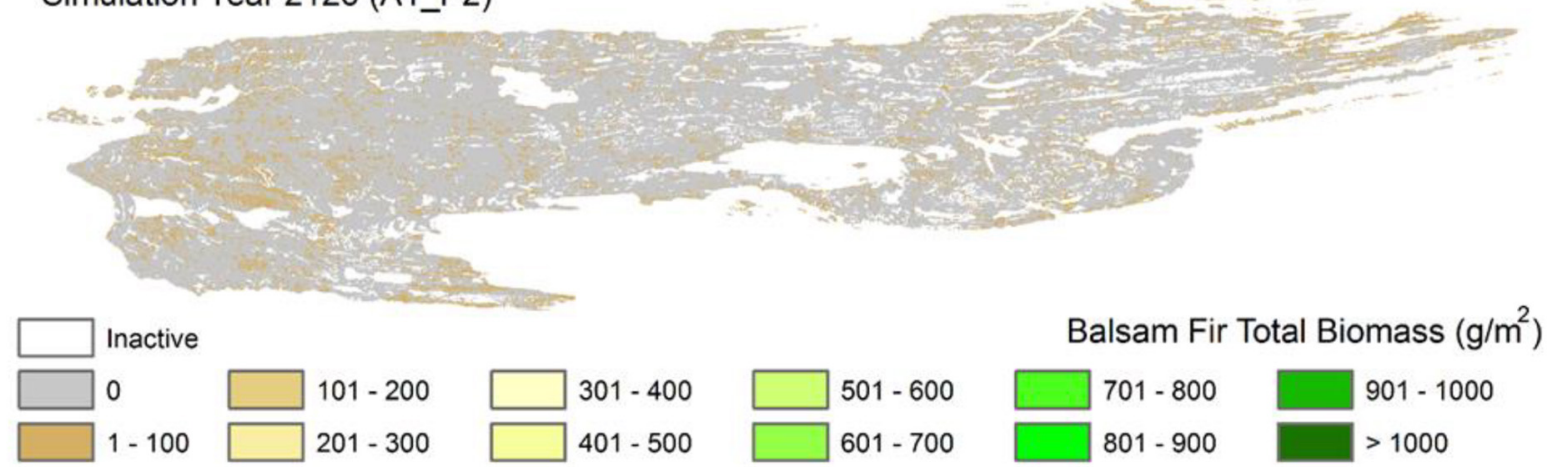

FIGURE 6 | Mapped distributions of balsam fir biomass for initial model conditions (simulation year 2006) and after 120 years of current climate and no predation (CC_P0), current climate and strong predation (CC_P2), high emissions and no predation (A1FI_P0), and high emissions and strong predation (A1FI_P2). 
climate in general (Intergovernmental Panel on Climate Change [IPCC], 2013) or for Isle Royale National Park, and we cannot represent every individual species interaction. Additionally, our simulations are based on models and model parameterization that introduce additional uncertainty. In general, our predictions regarding near-term dynamics ( $<50$ years) are probably more robust than those for the longer term (after 100 years). Our nearterm projections reflect an initial landscape with a mix of boreal conifer and hardwood species with a relatively high suitability for moose. Although our process for imputing forest plot data into cells across the landscape introduces some uncertainty, the degree of uncertainty is likely much less than for model projections of plant communities 100 years into the future. In addition, the uncertainty in the magnitude of climate changes and their effects on plant growth and establishment increase with time. Thus, our insights into the way management agencies might think about the roles of predation, ungulate population, and forest management in a changing climate could be interpreted considering the assumptions and uncertainty inherent to our methods.

Our primary finding is that the direct effects of moose population management via reintroduction of wolves is likely to be effective while wolf-moose interactions play out on the current mixed boreal forest landscape of Isle Royale and under a climate suitable for boreal plant species. However, in the longer term, and perhaps considered with a greater degree of uncertainty, the effects of predator reintroduction may become increasingly ineffective as the forest shifts toward late successional conifers and as the climate continues to warm because forest composition and productivity may not be sufficient to support a moose population at all. On the other hand, the marginal effects of predation under the climate change scenario could be viewed as essential to maintaining a small moose population and prevent that population from exhausting the few forage resources that remain. Even so, our projections imply that Isle Royale is likely to undergo changes in composition and productivity that make the island increasingly unsuitable for moose.

Our modeling efforts assume that the National Park Service will continue to allow the forests of Isle Royale to undergo forest successional changes in absence of major stand replacing disturbances such as fire or timber harvesting. This is a feature of Isle Royale that makes it different from most other boreal forests that support large moose populations (e.g., Alaska, Sweden). At the start of our model simulations, a mixed landscape of boreal hardwood and conifer forests supported a relatively large carrying capacity for moose and moose were removing biomass from the landscape in accordance with published foraging preferences (boreal hardwoods $>$ balsam fir $>$ northern hardwoods $>$ northern conifers). But the boreal hardwood and conifer communities diverged within the first 30 to 50 years of our simulations, regardless of the effects of climate change or predation. As these successional changes occurred, the carrying capacity of the landscape for moose declined significantly and moose began to rely increasingly heavily on later successional balsam fir.

The abundance and initial age structure of the early successional aspen and birch forests may reflect a history of small-scale timber harvests and forest fires that were coincident with copper mining and tourism on the island during the early 1900s (Krefting, 1974). Then, in 1936 a large fire reset the forest successional sequence over a large central portion of the island and may have been responsible for sustaining the moose population (Scarpino, 2011), as there were reports that the population had exhausted its food supply (Krefting, 1974). Since that time period there have been no large-scale stand replacing disturbances on the island and the current aspenbirch forests are approaching their longevity. We did simulate smaller-scale wind patch disturbance events reflecting the low intensity and high frequency wind blowdown events on the island (Kirschbaum and Gafvert, 2012). These simulated wind events created local increases in forage availability of select species (Figure A2) but did not alter the landscape as dramatically as a much larger disturbance, such as the 1936 fire would, for example. The absence of larger scale forest disturbances or management actions to regenerate these early successional forests resulted in significant declines in both the quantity and quality of forage for moose across the island and changes in foraging behavior that do not correspond with published observations from earlier successional forests. Finally, it has been suggested that the frequency and/or intensity of large scale fires could increase at Isle Royale under a changing climate (Fisichelli et al., 2013). In the near-term, while climate change impacts on the establishment and growth of early successional boreal species such as aspen and birch are projected to be more minor, stand replacing fires would be expected to increase the suitability of Isle Royale for moose. However, it is less clear how such disturbances would impact the suitability of this landscape for moose late in time, when the effects of climate change on these species is stronger.

Finally, in this study, we focused our attention on the effects of climate change on plant growth and establishment rates, and how such effects may interact with variable rates of moose browsing to alter forest dynamics in space and time. However, it has been suggested that climate change may directly impact moose survival, especially in areas near their summer range limit (Thompson et al., 1998; Murray et al., 2006; Lenarz et al., 2010). Within our modeling framework, increased moose mortality due to the direct effects of heat stress would result in lower moose population densities and weaker effects on forest resources than we simulated in the strong predation/high emissions scenario. A recent global analysis by Timmermann and Rogers (2017) found that 10 of 15 moose populations near their summer range limit were stable or increasing, including the Isle Royale population, and indicated that climate change may pose no immediate threat to moose populations. However, the projected changes in climate that we simulated here are larger than what has been observed during the recent past and could become physiologically unsuitable for moose over the next 100 years. More generally, our approach to modeling moose population dynamics relies on estimates of carrying capacity, which are derived from annual estimates of the total available forage across the landscape and the estimated yearly forage requirements for an average moose. As a result, our estimates of carrying capacity are likely an over-estimation of the population density expected to be supported by forage resources. A more physiologically based approach would allow for an evaluation of the direct effects of 
climate change on the moose population or any other factor that may cause moose mortality long before the population reaches carrying capacity based on forage quantity alone.

\section{DATA AVAILABILITY STATEMENT}

Publicly available datasets were analyzed in this study. This data can be found here: https://www.nps.gov/im/vmi-isro.htm.

\section{AUTHOR CONTRIBUTIONS}

ND conceived the study, conducted the modeling, analyzed the results, and wrote the manuscript. JR prepared the input data files, conducted GIS analyses, and edited the manuscript. MD provided the input parameters derived from previous climate change modeling work and edited the manuscript. All authors contributed to the article and approved the submitted version.

\section{FUNDING}

Funding support for this research was provided by the Natural Resources Preservation Program, a joint National Park Service -

\section{REFERENCES}

Allen, D. L. (1993). Wolves of Minong: Isle Royale's Wild Community. Ann Arbor, MI: University of Michigan.

Bergeron, Y. (2000). Species and stand dynamics in the mixed woods of Quebec's southern boreal forest. Ecology 81, 1500-1516. doi: 10.1890/0012-9658(2000) 081[1500:sasdit]2.0.co;2

Brandner, T. A., Peterson, R. O., and Risenhoover, K. L. (1990). Balsam fir on Isle Royale: effects of moose herbivory and population density. Ecology 59, 155-164. doi: $10.2307 / 1940256$

Cabral, J. S., Weigelt, P., Kissling, W. D., and Kreft, H. (2014). Biogeographic, climatic and spatial drivers differentially affect $\alpha$-, $\beta$-and $\gamma$-diversities on oceanic archipelagos. Proc. Biol. Sci. 281, 20133246. doi: 10.1098/rspb.2013. 3246

Daly, C., and Gibson, W. (2002). 103-Year High-Resolution Temperature Climate Data Set for the Conterminous United States. Oregon: Oregon State University.

Danell, K., Bergström, R., Duncan, P., and Pastor, J. (2006). Large Herbivore Ecology, Ecosystem Dynamics, And Conservation. Cambridge: Cambridge University Press.

De Jager, N. R., and Pastor, J. (2008). Effects of moose population density and site productivity on the canopy geometries of birch (Betula pubescens and $B$. pendula) and Scots pine (Pinus sylvestris). Wildlife Biol. 14, 251-262.

De Jager, N. R., Drohan, P. J., Miranda, B. M., Sturtevant, B. R., Stout, S. L., Royo, A. A., et al. (2017a). Simulating ungulate herbivory across forest landscapes: a browse extension for LANDIS-II. Ecol. Mod. 350, 11-29. doi: 10.1016/j. ecolmodel.2017.01.014

De Jager, N. R., Rohweder, J. J., Miranda, B. R., Sturtevant, B. R., Fox, T. J., and Romanski, M. C. (2017b). Modelling moose-forest interactions under different predation scenarios at Isle Royale National Park. USA. Ecol. App. 27, 1317-1337. doi: 10.1002/eap.1526

De Jager, N. R., Pastor, J., and Hodgson, A. L. (2009). Scaling the effects of moose browsing on forage distribution, from the geometry of plant canopies to landscapes. Ecol. Mono. 79, 281-297. doi: 10.1890/08-0149.1

Delworth, T. L., Broccoli, A. J., Rosati, A., Stouffer, R. J., Balaji, V., Beesley, J. A., et al. (2006). GFDL's CM2 global coupled climate models: Part I: Formulation and simulation characteristics. J. Clim. 19, 643-674.

Demarais, S., Cornicelli, L., Kahn, R., Merrill, E., Miller, C., Peek, J. M., et al. (2012). Ungulate Management In National Parks Of The United States And Canada. Bethesda, MD: The Wildlife Society.
U.S. Geological Survey program focused on conducting scientific research in the U.S. National Parks. Any mention of trade, firm, or product names does not imply endorsement by the U.S. Government.

\section{ACKNOWLEDGMENTS}

We thank anyone who contributed to previous modeling efforts focused on generating input parameters related to climate change, forest succession, and ungulate browsing within the LANDIS-II framework. Without these previous efforts, this study would not have been possible. We thank John Delaney (USGS), and two anonymous reviewers for helpful comments on earlier drafts of the manuscript. Accompanying data for this study are available at: https://doi.org/10.5066/F7RJ4GKW.

\section{SUPPLEMENTARY MATERIAL}

The Supplementary Material for this article can be found online at: https://www.frontiersin.org/articles/10.3389/fevo.2020. 543915/full\#supplementary-material

Duveneck, M. J., and Scheller, R. M. (2015b). Measuring and managing resistance and resilience under climate change in northern Great Lake forests (USA). Landsc. Ecol. 31, 669-686. doi: 10.1007/s10980-015-0273-6

Duveneck, M. J., and Scheller, R. M. (2015a). Climate change effects to productivity and functional diversity in northern Great Lake forests with climate suitable planting. Ecol. App. 25, 1653-1668. doi: 10.1890/14-0738.1

Duveneck, M. J., Scheller, R. M., White, M., Handler, A. S., and Ravenscroft, C. (2014a). Climate change effects on northern Great Lake (USA) forests: A case for preserving diversity. Ecosphere 5, 23. doi: 10.1890/ES13-00370.1

Duveneck, M. J., Scheller, R. M., and White, M. A. (2014b). Effects of alternative forest management strategies in the face of climate change in the northern Great Lake region. Can. J. Forest Res. 44, 700-710. doi: 10.1139/cjfr-2013-0391

Fisichelli, N., Frelich, L. E., and Reich, P. B. (2012). Sapling growth responses to warmer temperatures 'cooled' by browse pressure. Global. Change Biol. 18, 3455-3463. doi: 10.1111/j.1365-2486.2012.02785.x

Fisichelli, N., Hawkins Hoffman, C., Welling, L., Briley, L., and Rood, R. (2013). Using Climate Change Scenarios To Explore Management At Isle Royale National Park: January 2013 Workshop Report. Washington, D. C: National Park Service.

Frelich, L. E., and Reich, P. B. (2009). Wilderness conservation in an era of global warming and invasive species: a case study from Minnesota's Boundary Waters Canoe Area Wilderness. Nat. Areas J. 29, 385-393. doi: 10.3375/043.029.0405

Fritts, H. C. (1976). Tree rings and climate. London: Academic Press.

Goldblum, D., and Rigg, L. S. (2010). The deciduous forest-boreal forest ecotone. Geog. Comp. 4, 701-717. doi: 10.1111/j.1749-8198.2010.00342.x

Gonzalez, P., Neilson, R. P., Lenihan, J. M., and Drapek, R. J. (2010). Global patterns in the vulnerability of ecosystems to vegetation shifts due to climate change. Global Ecol. Biogeo. 19, 755-768. doi: 10.1111/j.14668238.2010.00558.x

Handler, S., Duveneck, M. J., Iverson, L., Peters, E., Scheller, R. M., Wythers, K. R., et al. (2013). Michigan forest ecosystem vulnerability assessment and synthesis: A report from the Northwoods Climate Change Response Framework General Technical Report NRS-129. Washington, D.C: USDA Forest Service.

Hobbs, N. T. (1996). Modification of ecosystems by ungulates. J. Wildlife Man. 60, 695-713. doi: $10.2307 / 3802368$

Hodgson, A. L. (2010)). Temporal Changes In Spatial Patterns Of Moose Browse: Causes And Consequences. dissertation, Minnesota, USA: University of Minnesota.

Intergovernmental Panel on Climate Change [IPCC] (2013). Climate Change 2013: The Physical Science Basis. Cambridge, UK: Cambridge University Press. 
Intergovernmental Panel on Climate Change [IPCC] (2007). Climate Change 2007: The Physical Science Basis: Contribution Of Working Group I To The Fourth Assessment Report Of The Intergovernmental Panel On Climate Change. Cambridge, UK: Cambridge University Press.

Iverson, L. R., Prasad, A. M., Matthews, S. N., and Peters, M. (2008). Estimating potential habitat for 134 eastern US tree species under six climate scenarios. Forest Ecol. and Man. 254, 390-406. doi: 10.1016/j.foreco.2007.07.023

Kirschbaum, A. A., and Gafvert, U. B. (2012). Landsat-Based Monitoring Of Landscape Dynamics At Isle Royale National Park, 2003-2008. Washingto, DA: National Park Service.

Krefting, L. W. (1974). The Ecology of the Isle Royale Moose with Special Reference to the Habitat. Minneapolis, MN: University of Minnesota.

Kunkel, K. E., Karl, T. R., Easterling, D. R., Redmond, K., Young, J., Yin, X., et al. (2013). Probable maximum precipitation and climate change. Geophys. Res. Letters. 40, 1402-1408. doi: 10.1002/grl.50334

Lenarz, M. S., Fieberg, J., Schrage, M. W., and Edwards, A. J. (2010). Living on the edge: Viability of moose in northeastern Minnesota. J. Wild. Man. 74, 1013-1023. doi: 10.2193/2009-493

Liang, Y., Duveneck, M. J., Gustafson, E., Serra Diaz, J., and Thompson, J. (2017). How disturbance, competition and dispersal interact to prevent tree range boundaries from keeping pace with climate change. Global Ch. Biol. 24, e335-e351. doi: 10.1111/gcb.13847

McInnes, P., Naiman, R. J., Pastor, J., and Cohen, Y. (1992). Effects of moose browsing on vegetation and litter of the boreal forest, Isle Royale, Michigan, USA. Ecology 73, 2059-2975. doi: 10.2307/1941455

Monahan, W. B., and Fisichelli, N. A. (2014). Climate change exposure of US National Parks in a new era of change. PLoS One 9:e101302. doi: 10.1371/ journal.pone.0101302

Murie, A. (1934). The moose of Isle Royale: University of Michigan Museum of Zoology Miscellaneous Publication number 25. Michigan: University of Michigan Press.

Murray, D. L., Cox, E. W., Ballard, W. B., Whitlaw, H. A., Lenarz, M. S., Custer, T. W., et al. (2006). Pathogens, nutritional deficiency, and climate influences on a declining moose population. Wildlife Mono. 166, 1-30. doi: 10.2193/00840173(2006)166[1:pndaci]2.0.co;2

National Park Service [NPS] (2017). Environmental Impact Statement to Address the Presence of Wolves at Isle Royale National Park. Houghton, MI: National Park Service.

O’Neill, B. C., Tebaldi, C., van Vuuren, D. P., Eyring, V., Friedlingstein, P., Hurtt, G., et al. (2016). The Scenario Model Intercomparison Project (ScenarioMIP) for CMIP6. Geosci. Model Dev. 9, 3461-3482. doi: 10.5194/gmd-9-3461-2016

Parikh, G. L. (2015). The influence of diet composition, plant defensive chemicals, and winter severity on the nutritional condition of a free ranging generalist herbivore. thesis, Michigan Technological University: Michigan, USA:.

Pastor, J., and Danell, K. (2003). Moose-vegetation-soil interactions: a dynamic system. Alces 39, 177-192.

Pastor, J., Dewey, B., Naiman, R. J., McInnes, P. F., and Cohen, Y. (1993). Moose browsing and soil fertility in the boreal forests of Isle Royale National Park. Ecology 74, 467-480. doi: 10.2307/1939308

Pastor, J. J., and Naimen, R. J. (1992). Selective foraging and ecosystem processes in boreal forests. Am. Natural. 139, 690-705. doi: 10.1086/285353

Peters, G. P., Andrew, R. M., Boden, T., Canadell, J. G., Ciais, P., Le Quéré, C., et al. (2012). The challenge to keep global warming below $2{ }^{\circ} \mathrm{C}$. Nat. Clim. Ch. 3, 4-6. doi: $10.1038 /$ nclimate 1783

Peterson, R. O., and Page, R. E. (1988). The rise and fall of Isle Royale wolves, 1975-1986. J. Mamm. 69, 89-99. doi: 10.2307/1381751

Peterson, R. O., Vucetich, J. A., Bump, J. M., and Smith, D. W. (2014). Trophic cascades in a multicausal world: Isle Royale and Yellowstone. Ann. Rev. Ecol. Evol. Sys. 45, 325-345. doi: 10.1146/annurev-ecolsys-120213-091634

Raupach, M. R., Marland, G., Ciais, P., Le Quéré, C., Canadell, J. G., Klepper, G., et al. (2007). Global and regional drivers of accelerating CO2 emissions. Proc. Nat. Acad. Sci. 104, 10288-10293. doi: 10.1073/pnas.0700609104

Reich, P. B., and Oleksyn, J. (2008). Climate warming will reduce growth and survival of Scots pine except in the far north. Ecol. Lett. 11, 588-597. doi: 10.1111/j.1461-0248.2008.01172.x

Ripple, W. J., and Beschta, R. L. (2012). Trophic cascades in Yellowstone: the first 15 years after wolf reintroduction. Biol. Conserv. 145, 205-213. doi: 10.1016/j. biocon.2011.11.005
Risenhoover, K. L. (1987). Winter foraging strategies of moose in subarctic and boreal forest habitats. dissertation, Michigan Technological University: Michigan, USA.

Rotter, M. C., and Rebertus, A. J. (2015). Plant community development of Isle Royale's moose-spruce savannas. Botany 93, 75-90. doi: 10.1139/cjb-2014-0173

Sanders, S., and Grochowski, J. (2013). The forests of Isle Royale National Park: Can we preserve this pristine wilderness in the face of climate change? Nat. Areas J. 33, 66-77. doi: 10.3375/043.033.0108

Scarpino, P. V. (2011). Isle Royale National Park: balancing human and natural history in a maritime park. George Wright Form. 28, 182-198.

Scheller, R. M., Domingo, J. B., Sturtevant, B. R., Williams, J. S., Rudy, A., Gustafson, E. J., et al. (2007). Design, development and application of LANDISII, a spatial landscape simulation model with flexible temporal and spatial resolution. Ecol. Model. 201, 409-419. doi: 10.1016/j.ecolmodel.2006.10.009

Scheller, R. M., and Mladenoff, D. J. (2004). A forest growth and biomass module for a landscape simulation model. LANDIS: design, validation, and application. Ecol. Model. 180, 211-229. doi: 10.1016/j.ecolmodel.2004.01.022

Sell, S. M. (2007). Interactions between moose and their primary forage at Isle Royale National Park, Lake Superior. dissertation, University of Minnesota: Minnesota.

Snyder, J. D., and Janke, R. A. (1976). Impact of moose browsing on boreal-type forests of Isle Royale National Park. Am. Midl. Nat. 95, 79-92. doi: 10.2307/ 2424235

Stoner, A. M. K., Hayhoe, K., Yang, X., and Wuebbles, D. J. (2012). An asynchronous regional regression model for statistical downscaling of daily climate variables. Int. J. Clim. 33, 2473-2494. doi: 10.1002/joc.3603

Terborgh, J., Estes, J. A., Paquet, P., Ralls, K., Boyd-Heiger, D., Miller, B. J., et al. (1999). "The role of top carnivores in regulating terrestrial ecosystems," in Continental Conservation: Scientific Foundations of Regional Reserve Networks, eds J. Terborgh and M. Soulé (Washington, DC: Island Press), 39-64.

The Nature Conservancy [TNC] (1999). USGS-NPS Vegetation Mapping Program: Classification of the Vegetation of Isle Royale National Park. Michigan: Isle Royale National Park.

Thompson, I. D., Flannigan, M. D., Wotton, B. M., and Suffling, R. (1998). The effects of climate change on landscape diversity: an example in Ontario forests. Environ. Monit. Assess. 49, 213-233.

Timmermann, H. R., and Rogers, A. R. (2017). The status and management of moose in North America: circa 2015. Alces 53, 1-22.

Vanderwel, M. C., and Purves, D. W. (2013). How do disturbances and environmental heterogeneity affect the pace of forest distribution shifts under climate change? Ecography 37, 10-20. doi: 10.1111/j.1600-0587.2013.00345.x

Vucetich, J. A., Hebblewhite, M., Smith, D. W., and Peterson, R. O. (2011). Predicting prey population dynamics from kill rate, predation rate and predator-prey ratios in three wolf ungulate systems. J. Anim. Ecol. 80, 12361245. doi: 10.1111/j.1365-2656.2011.01855.x

Vucetich, J. A., Nelson, M. P., and Peterson, R. O. (2012). Should Isle Royale wolves be reintroduced?: A case study on wilderness management in a changing world. George Wright Forum. 29, 126-147.

Woudenberg, S. W., Conkling, B. L., O'Connell, B. M., LaPoint, E. B., Turner, J. A., and Waddell, K. L. (2010). The Forest Inventory and Analysis Database: Database Description and Users Manual Version 4.0 for Phase 2. Washington, DA: U.S. Department of Agriculture.

Xu, C. G., Gertner, G. Z., and Scheller, R. M. (2009). Uncertainties in the response of a forest landscape to global climatic change. Global Ch. Biol. 15, 116-131. doi: $10.1111 / j .1365-2486.2008 .01705 . x$

Web Soil Survey (2011). Soil Survey Staff, Natural Resources Conservation Service, United States Department of Agriculture. Available online at: https: //websoilsurvey.nrcs.usda.gov/

Conflict of Interest: The authors declare that the research was conducted in the absence of any commercial or financial relationships that could be construed as a potential conflict of interest.

Copyright $\odot 2020$ De Jager, Rohweder and Duveneck. This is an open-access article distributed under the terms of the Creative Commons Attribution License (CC BY). The use, distribution or reproduction in other forums is permitted, provided the original author(s) and the copyright owner(s) are credited and that the original publication in this journal is cited, in accordance with accepted academic practice. No use, distribution or reproduction is permitted which does not comply with these terms. 